\title{
Entrepreneurship and Equity Crowdfunding: A Research Agenda
}

\begin{abstract}
:
The potential of 'the crowd' to enhance investments, especially at levels previously that could reduce the financial constrain faced by new ventures, has led to the introductions of regulations to facilitate crowdfunding activities. One of regulated areas is equity crowdfunding, which has the potential to disrupt the existing market provision for equity finance to early stage firms. This paper aims to provide a theoretical review of the extant literature and develop from that review an agenda for future research. The results identify, from the perspective of entrepreneurs, equity investors and government, the key issues that potentially differentiate crowdfunding from other sources of equity finance and how these issues change the relationship between entrepreneurs and potential funders. Based upon the findings of the theoretical review, the paper suggests research directions in which future researchers can employ behaviour theory, agency theory and signalling theory to explore, investigate and accomplish our understanding about equity crowdfunding in the entrepreneurial context.
\end{abstract}

Keywords: Equity Crowdfunding, Entrepreneurship, Systematic Review, Research Agenda.

\section{Introduction}

A scarcity of early-stage financing limits the ability of new ventures to develop their inventions and knowledge into practical commercial applications (Lindstrom and Olofsson 2001, Widding et al. 2009). The imperfections of capital market caused by the uncertainty of investment returns, the asymmetric information between entrepreneurs and potential investors, and the lack of collateral available to entrepreneurs create financial constraints and funding gaps for new 
ventures (Carpenter and Petersen 2002, Hellmann 2007, Chen et al. 2009, Kirsch et al. 2009). It is difficult for new ventures to gain access to external finance in the early stages of development because traditional investors (e.g. banks, business angels and venture capitalists) are attracted to the more cost effective and less risky investments available in established firms. Thus, entrepreneurs usually utilise their own capital or that from family and friends to finance proof-ofconcept and other early star-up costs (Dushnitsky and Shapira 2010).

Within the context of start-up finance, Shane and Cable (2002) and Zhang and Wong (2008) suggested that social networks may provide a solution to early-stage financing gaps leading to an assumption that online social networks provide access to a new source named crowdsourcing. Latterly, Shiller (2013) indicated that resources dispersed over millions of people must be activated to successfully grow an economy and crowdsourcing is one mean to do that.

Much recent interest has been paid to crowdsourcing among scholars in management and entrepreneurship studies. While most early contributions focused on crowd resources (Hempel 2006, Howe 2006), more recent works have focused upon contribution a crowd can make to "open innovation", a combination of open resources and innovation concepts (Gruber and Henkel 2006), and the ability of the crowd to collate financial resources (Cumming and MacIntosh 2006, Ordanini et al. 2011). Moreover, the rising interest in crowdfunding is evidenced by the rise in the number of refereed journal articles across a range of themes, including process, platforms, the dynamics of operation (Ordanini et al. 2011, Wieck et al. 2013, Mollick 2014), and regulations that manipulate the relations between financial receivers and crowd funders (Bradford 2012, Lehner 2013, Stemler 2013). 
Crowdfunding, a recent development, has sought to overcome the problems faced by new ventures by utilizing a large dispersed audience, 'the crowd', to contribute relatively small sums of money by using an open call, commonly through the internet (Sigar 2012, Lehner 2013, Belleflamme et al. 2014). Crowdfunding has been used for various purposes, for example to fund research projects (Cameron et al. 2013, Loucks 2013), film, music and game projects (Sorensen 2012, Weigmann 2013), and new firm start-ups (Ibrahim and Verliyantina 2012, Lehner 2013). (Belleflamme et al. 2014) and Wieck et al. (2013) classify crowdfunding into four groups: Donation-based crowdfunding occurs when crowd funders do not receive any offered rewards; debt-based crowdfunding allows the crowd funders lend money to founders and receive interest in return for funds; founders offer products or services to crowdfunders under the form of preordering in reward-based crowdfunding; and equity-based crowdfunding enable crowdfunders to receive a financial compensation such as equity, revenue, profit-share arrangements.

Shiller (2013) inferred that the financial issue of start-ups can be resolved by an innovative method of securitization named equity crowdfunding. It is because (a) by increasing the number of investors and the amount invested, and (b) by changing the investor/investees relationship due to possible changes in investor objectives and investor interference. In fact, upon signing the JOBS (Jumpstart our business start-up) act, President Obama remarked on equity crowdfunding that "for start-ups and small businesses, this bill is a potential game changer" (Mollick 2014). However, being new phenomena, our understanding about the nature of equity crowdfunding and its contributions to entrepreneurial activities is still limited. Thus, this study attempts to survey and draw together the equity crowdfunding element of entrepreneurship studies, to review the past research in this field, and to outline opportunities for potential further research in equity crowdfunding under the entrepreneurship context. 
In doing so, a systematic review (Tranfield et al. 2003) and a 'fit for purpose' methodology (Macpherson and Jones 2010) are adopted to categorize and classify the existing literature in order to collate a knowledge base that summarises our current understanding of the crowdfunding phenomena. This paper then reviews the diffusion of equity crowdfunding in entrepreneurship studies which have been published in Social Sciences Citation Index (SSCI) and elsewhere up to December 2014. To undertake the research, 'protocol driven' and 'snowballing' methods (Greenhalgh and Peacock 2005) have been employed. Because crowdfunding is a new research domain and only a minority of academic articles specifies equity crowdfunding, this paper will collect all papers with titles, abstracts or keywords containing the expression 'crowdfunding' published in the SSCI and Business Source Complete databases. These papers will be systematically reviewed to construct the knowledge base of equity crowdfunding. An initial set of 77 papers were obtained. However, this study will exclude 38 papers which are short essays representing personal reflections. Thus, in total, this study reviews 39 papers published by the end of 2014 .

All collected literature was read to identify the core themes of research in relation to equity crowdfunding; these were identified as equity crowdfunding in entrepreneurship context, fund receivers (entrepreneurs), crowdfunders, and regulatory environment (the government). To present the findings of this study, the paper firstly describes how crowdfunding was conceptualised in management studies before exploring the notion of equity crowdfunding as an alternative source of funding for early stage firms. This will be undertaken through an analytical comparison between equity crowdfunding and others, more established sources of funds. The paper will scrutinize the equity crowdfunding within the context of early stage firms from the perspective of the investor, entrepreneur and government to highlight the contribution made by 
equity crowdfunding and possible gaps in the literature that could help inform future research. Finally, the paper suggests a research agenda for future scholars to adopt agency theory (Arthurs and Busenitz 2003), signalling theory (Connelly et al. 2011), and behaviour theory (Connelly et al. 2010) to explore, investigate, and accomplish our understanding about equity crowdfunding.

\section{Crowdfunding Conceptualization}

The concept of crowdfunding originates from the disciplines of micro-finance and crowdsourcing, but contains unique features facilitated by the rapid growth of the Internet (Poetz and Schreier 2012, Sorensen 2012, Mollick 2014). Crowdsourcing relates to activities in which a large group of participants (i.e., individuals, institutions, non-profit organization, or companies) respond to a flexible open call by undertaking voluntary tasks (Howe 2006, Brabham 2009, Bayus 2013, 2013, Schwartz 2013, Belleflamme et al. 2014). Crowdsourcing can benefit participants by creating a context in which ideas can be generated and through the creation of networks that provide feedback on those ideas which facilitates product development, the testing of early prototypes through to the funding of the process (Brabham 2009). It also triggers a new model of business development in which the ordinary crowd is deeply committed to a new venture as active customers, investors or both (Belleflamme et al. 2014).

In entrepreneurship, one of the biggest obstacles to transform an idea to a new offering to market is to find investors willing and able to take the risk associated with backing the project because most entrepreneurs are not independently wealthy (Riedl 2013). According to Lehner (2013), informal external investment associated with the friends and family of the founder, or other high net worth individuals (business angles) is already far more important than venture capital, and crowdfunding has the potential to enhance this form of investments. Unlike crowdsourcing 
which receives labour contributions, the purpose of crowdfunded projects is to raise capital directly through investments from large groups of interested people either as a donation or in consideration of some reward (Ordanini et al. 2011, Schwartz 2013).

In fact, crowdfunding model has been historically utilised to collect small amounts of money from many people for the charitable purposes and social cooperation (Ordanini et al. 2011). The successful services of intermediaries (e.g. Kickstarter, Indiegogo) in organizing crowdfunding activities attest the viability of this vehicle of attracting investment (Ordanini et al. 2011); in addition, the levels of investment from crowdfunding platforms have significantly increased suggesting that the new method of mobilising informal investment has considerable scope in the future (Belleflamme et al. 2013).

\section{From crowdfunding to equity crowdfunding}

Crowdfunding has been classified into various models. For example, Larralde and Schewienbacher (2012) identify three crowdfunding models: donation, passive and active investments. Donation crowdfunding model in which the crowd does not receive any kind of return has been used for long time for the charitable purposes or non-profit institutions (Lehner 2013). The passive crowdfunding model involves some rewards for investors, such as products, honorary recognition or other forms of revenue shares, while the investors in the active crowdfunding models not only provide money but also bring the best manner of open sources. Other authors (2013, Wieck et al. 2013, Belleflamme et al. 2014, Mollick 2014) have categorised crowdfunding into four types: donation (patronage), lending, reward, and equity-based models and this approach seem to be most popular with scholars, governments and practitioners. Lending-based crowdfunding model allows crowdfunders to lend money to and receive interest 
from start-ups through internet platforms. Reward-based crowdfunding model in which entrepreneurs offer different nonfinancial rewards, for example acknowledgements, products, services, or creative rewards in return for investments is the most prevalent. In this model, crowdfunders are often treated as early customers, able to access product at an earlier date and offered better prices and/or other special benefits. This kind of pre-selling product model is a common choice of entrepreneurs who are producing novel software, hardware, or consumer products. Finally, start-ups or SMEs utilising equity-based crowdfunding offer shares in the company that confers part ownership to third parties in exchange for a cash injection (Schwartz 2013, Mollick 2014).

However, Lehner (2013) believes that the funds for donation purposes are highly completed and become scarce because the number of crowdfunding initiatives and platforms increase rapidly. When the crowd actually becomes shareholders of new ventures the donation-based crowdfunding is not an important alternative market. Additionally, studying individual crowdfunding practices, Belleflamme et al. (2013) found that donation-based crowdfinding model has become less common in practices, and most of crowdfunding projects offer either non-financial rewards (final products or tokens of appreciation) or financial compensations (equity or profit-share arrangement). In pre-order model, when the amount of capital required is significant, the entrepreneur will distort the offering prices to attract more participants. However, when the distortion is too large, the pre-order model is unlikely to be the best choice (Belleflamme et al. 2014).

Moreover, the rewarding function in the reward-based crowdfunding model will limit the interaction between a new venture and its investors (Lehner 2013). Furthermore, according to (Belleflamme et al. 2014), for larger capital needs, entrepreneurs prefer investments from 
investors rather than through pre-sales or reward in returns. In such cases, profit-shared crowdfunding model seems to economically benefit crowdfunders. The choice between debt and equity finance of investors and entrepreneurs is influenced by the stage and phase of ventures, aspects of risk dispersion, legal regulations, cooperate governance and reputation (Kreiser et al. 2010).

However, equity crowdfunding will become more inevitable (Larralde and Schewienbacher 2012) and is one of current financial innovation to allow simple projects to raise needed capital (Shiller 2013). Because this model essentially democratises the financing activities by allowing all kinds of investors (small or big) become venture capitalists (Shiller 2013), it requires the control of high-level regulation (Mollick 2014). Thus, Lehner (2013) concludes that current regulations are incomplete or still remain legal hurdles makes the equity crowdfunding model become less preferred than others in many countries. However, equity crowdfunding can be undertaken through other forms, such as shares of future profits or royalties, portions of future public offering or acquisitions, or other options (Sigar 2012, Mollick 2014).

\section{Equity crowdfunding vs. Traditional financing methods}

Traditional finance (provided by banks, business angels, venture capitalists) typically involves only a few experienced people or institutions rather than a large group of individuals. In contrast, because basing upon the internet, an equity crowdfunding campaign can easily and quickly reach more potential investors than a traditional way does (Schwartz 2013). Thus, the costs and risks per investor in equity crowdfunding projects are significantly lower than in traditional funding models (Ordanini et al. 2011). 
It is free for registration and attendant and lower cost to promote an equity crowdfunding project via the internet. The registration requirements and regulatory accompanying a public securities offering are too onerous; registration costs for public offering generated by the compliance with the extensive securities laws and regulation are too expensive and disproportionately burdensome on small offerings of entrepreneurs (Lehner 2013). Using a public offering of equity also incurs significant costs for entrepreneurs as a consequence of the necessary due diligence (Lehner 2013). Additionally, the promotion costs that call for public relations, catering, travel, printing, and many other types of specialists are expensive endeavours. Furthermore, equity crowdfunding issuers can avoid the costs for quarterly and annually obligational audited reports (Schwartz 2013). Instead of using the author's to-be-written book, equity crowdfunding takes the concept of one step further which allows entrepreneurs and investors to find one another on the internet (Schwartz 2013). In general, the outweigh-benefit costs may discourage and prevent entrepreneurs from raising capital from traditional resources (Cumming and Johan 2013).

Furthermore, the high investment thresholds, inability to diversify portfolio investments, investment costs (Loucks 2013), the limited number of solicited investors and actual investors, and the minimum wealth requirements of investors preclude many venture capitalists and business angels from investing to emerging growth companies (Cumming and Johan 2013). Thus, Loucks (2013) suggested a critical need for the bridge of financial market through the equity crowdfunding model. It is because equity crowdfunding allows the small and high-risk projects to be funded by both small and big investors (Riedl 2013), and helps entrepreneurs to collaborate with investors to undertake their entrepreneurial projects and manage new ventures (Belleflamme et al. 2014). The benefits of an equity crowdfunding model are not only the financial aspect but also contributions in production, promotion and distribution made by the 
crowd (Sorensen 2012). However, Sigar (2012) indicated that equity crowdfunding projects per se contain high risks with the uncertainties of crowdfunders about the project's legitimacy and development of products or services. They also have a high rate of failure and may face administrative and accounting challenges that require meticulous and laborious bookkeeping of a large number of shareholders.

\section{Equity crowfunding: crowdfunder, founder, and government perspectives}

\section{Crowdfunders}

The investment process in an equity crowdfunding model may go through three distinct phases (Ordanini et al. 2011). First, approximate half of the target capital will be obtained quickly by the rapid and significant investments from those have direct links with the projects or their creators, such as friends or family. The second phase is normally a more gradual growth of investment created by the desirability of the pitch and through word-of-mouth. Many projects fail at this phase primarily because of the inability to trigger the interest of the crowd. Finally, the investments will come from others who can access to the called project through the internet.

Through the conduit of the internet, equity crowdfunding is able to mobilise social networks in which online participants can share information, knowledge and suggestions, or select initiatives to support and provide financial capital (Ordanini et al. 2011). It is the participation by the crowd that creates the interest in social media that will attract more potential funders to the crowdfunding platform (Belleflamme et al. 2014). It is through these processes that entrepreneurs can have a global reach and access crowdfunders (Zahra et al. 2008, Zahra et al. 2009, Lehner 2013). 
In equity crowdfunding, the opportunity of an initiative has to be not only identified by entrepreneurs but also recognised and evaluated by the crowd (Lehner 2013). Unlike other traditional investors, crowdfunders are unlikely to use any analytic software tool to evaluate the feasibility and commercial potential of projects (Riedl 2013). Thus, entrepreneurs are suggested to use various instruments and strategies to communicate with a mass of heterogeneous people who can passively listen to available information or actively look for opportunities to make their commitment decisions (Lehner 2013).

The involvement of a crowdfunder is based upon his/her own personal motivations (Lehner 2013) will shift between passive and active depending upon the individual's motivation since, besides providing financial resources, they can contribute ideas, information and solutions, and support the start-up process (Larralde and Schewienbacher 2012). In an equity crowdfunding project, even contributing non-trivial amounts of money to early-stage ventures, crowdfunders also expect monetary returns from their investments (Ordanini et al. 2011). However, the majority of crowdfunders enjoy the investment experience which is linked to community benefits generated by the crowdfunding activity (Belleflamme et al. 2014). They enjoy the feeling of belonging to a group of special people, making an involved record in a special occasion, engaging in an innovative behaviour, being the first used highly interactive tools, and helping a friend or someone else to overcome a social or personal cause (Ordanini et al. 2011). In general, the participants are more likely to be motivated by the enthusiasm of the group of crowdfunders for the desired outcome of the new venture than ensuring monetary or other tangible incentives (Lehner 2013).

Ordanini et al. (2011) found that crowdfunders are from groups of people with unforeseen, chaotic and complex behaviours. Thus, a small omission of firm's action can lead to a hyperbolic 
response (Lehner 2013) and negatively influences the belief of potential investors (Ordanini et al. 2011). It leads to the fact that local investors are likely to invest earlier with more responsive decisions to projects created by trusted people even though equity crowdfunding is a global approach (Belleflamme et al. 2014).

\section{Founders}

Similar to other traditional funding methods, information asymmetry between entrepreneurs and crowdfunders is a challenge in any equity crowdfunding model (Belleflamme et al. 2014). To mitigate these difficulties, entrepreneurs rely upon the capabilities of the internet (Lehner 2013) to establish their connections with the crowd during the funding process (Belleflamme et al. 2014). This process enables the entrepreneur to communicate to a global audience the potential of the idea and the qualities of the founding teams (Lehner 2013).

Riedl (2013) found that entrepreneurs who already have large social networks are likely to be more successful in equity crowdfunding than those whose existing social networks are narrow. It is because social networks can help potential investors to access information related to the characteristics and reputation of entrepreneurs, and social information about other crowdfunder's decisions. However, according to Belleflamme et al. (2014), a successful equity crowdfunding is likely to rely on the quality of start-up toward possibility of delivering promised products or services rather than the quality of products or services.

To accurately provide credible signals and disclosure information about the quality of start-ups (Belleflamme et al. 2014), and to ensure that the process of an equity crowdfunding project was appropriately managed, Ley and Weaven (2011) suggest entrepreneurs need to have an initial screening criterion, and Weigmann (2013) advises creating a good website with a convincing 
video. All provided information should show that the project is technically savvy that consumers can appreciate and value (Riedl 2013), and must contain the start-up’s financial roadmap, board structure, and risk factors (Cumming and Johan 2013). Ordanini et al. (2011) also found that a project without a minimum individual investment target is likely to attract more participants with small amounts of contributions. In contrast, an equity crowdfunding project is likely to fail if it requires too much funds, or already received external certifications such as awards and government grants because the crowd assume that the project were valuable then they do not need to raise any external equity (Cumming and Johan 2013).

\section{Governments}

Mollick (2014) found that there has been a new trend in studying and exploring the potential and risks associated with equity crowdfunding to identify adequate policy action. Both intermediaries and policy makers are suggested to help entrepreneurs to create realistic plans and goals to ensure that their crowdfunding projects are low rate of fraud and high rate of growth. Thus, many countries including the United State, European state members, and Australia have introduced equity crowdfunding Acts to encourage and stimulate the innovation and entrepreneurship. These Acts have been established as exemptions to the Securities Act creating a big change in securities regulation in many ways (Schwartz 2013).

First, the crowdfunding Act allows SMEs and start-ups to sell securities to not only business angels and venture capitalists, but also friends, relations and other investors through the internet. Second, the Act does not require a minimum investment per individual, and there is no limit on the number of investors leading to a possibility of huge number of investors involved in a project. However, the regulation limits the maximum amount money that each individual can 
invest each year to protect crowdfunders from potential loss, and a start-up can raise as a registration constraint applied to equity crowdfunding (Belleflamme et al. 2014). Finally, crowdfunding intermediaries are required to ensure that each investor understands the risk generally applicable to investments start-ups, the risk of illiquidity, and other appropriate matters. Such intermediaries have to check the background of the issuer's directors, officers, and substantial investors and provide such disclosures to reduce the risk of fraud, and authorizes actions against those "make untrue” or omit statements to mislead the investors (Schwartz 2013).

To leverage the equity crowdfunding activity of new start-ups, the regulation only requires a basic disclosure such as the name, legal status, address, website, the names of directors and officers, business plans, and financial conditions. Moreover, successful crowdfunded issuers have to provide annual reports of its financial statements and operational results. Issuers must offer their shares through the registered crowdfunding portal, and self-offerings are prohibited (Schwartz 2013). These crowdfunded securities can be transferred between investors after one year or between family members. Thus, the secondary market of crowdfunded securities will be very small due to the number of share's orders from an equity crowdfunding issuer is smaller than in a registered one (Schwartz 2013).

Cumming and Johan (2013) found that, in general, crowdfunders require more disclosure information from start-ups, a limitation on the number of entrepreneurs can raise crowdfunds, and a lower threshold of audited financial statements. Meanwhile, entrepreneurs prefer fewer disclosure requirements and restrictions on the ability to crowdfund, and a free trading of crowdfunded shares as well. Investors and portals are indifferent to crowdfunding laws, but both prefer non-strict regulations in order to maximise the crowdfunded capital and want strict regulations and mechanisms related to risk mitigation. 


\section{Proposed research agenda}

The results from literature review have revealed the limits of our understanding about the nature of equity crowdfunding and its contributions to entrepreneurial activities. Thus, this paper proposes a research agenda for future equity crowdfunding studies in the entrepreneurial context towards three perspectives: Crowdfunders, entrepreneurs, and government.

\section{Crowdfunders}

Equity crowdfunding activities are facilitated by the internet, and involved funders who will be from a group of heterogeneous people. Because each individual has different values, selfpictures, needs and wants, it is difficult to predict the decision of a large heterogeneous crowd that behaves in unforeseen, chaotic and complex manners (Lehner 2013). Thus, further research on the individual explanations of funders in the equity crowdfunding needs to be undertaken. Being a new topic, our understanding about the decisions of crowdfunders to commit financially to start-ups is still limit. Thus, this paper would suggest future researchers to employ behaviour theory (Connelly et al. 2010) and grounded theory method to study the decisions and incentives of investors in equity crowdfunding.

Schwartz (2013) indicated that a limited disclosure of an equity crowdfunding project is likely to increase fraud and inaccurate information. Unlike other registered security method, equity crowdfunders have to make their decisions based upon such limited information provided by entrepreneurs through online platforms. It means either small or high net worth investors (business angels and venture capitalists) can not apply the normal due diligence process. Thus, a different study on special due diligence process for equity crowdfunders needs to be undertaken 
to help investors to acknowledge how to evaluate the provided data, market risk, people risk, technology risk, and monetary risk, and to make the investment decision.

\section{Entrepreneurs}

In equity crowdfunding, how to attract crowdfunders is the key element of a project. This depends on the business plan and communication strategy of the entrepreneurs. A business plan can be consist of market opportunity, product or service explanations, business model, people involved, financial, strategy, and dilution schedule. Although, Belleflamme et al. (2014) believe that an equity crowdfunding project per se serve as a signal of high-quality, this study proposes a future research on how to write a business plan and chose communication strategy to attract more investors in the condition that the internet platforms normally allow entrepreneurs to provide limited information.

In entrepreneurship research, the potential investors assess the readiness of new ventures to move to the next level when making an investing decision (Wiltbank et al. 2009). Each investor has different scales and ratings of the new venture's readiness basing upon technology, market, and management stage (Douglas and Shepherd 2002), or the business, risk/returns ratio, and time to exit (Wiltbank et al. 2009). Additionally, studying the early stage financing of new ventures, other scholars have found that the funding decisions depend on the investor's perception of management skills, business model, potential market, growth perspective (Mason and Harrison 2004), shortcut heuristic (Maxwell et al. 2011), and the presentation of entrepreneurs (Clark 2008). In general, potential investors trend to look for the signal of future success from the new ventures when making funding decisions (Meseri and Maital 2001). Thus, this study suggests 
future researchers to employ investment readiness to study how a good equity crowdfunding proposal must be.

Furthermore, how large are the number of crowdfunders and the amount of capital needed for an equity crowdfunding project is a challenged question. So far, the current literature has not addressed this challenge and the entrepreneurs have to make their own decisions based on their experience or personal advisors. A studying about the methods of financial forecasting and assessing financial needs is required to help entrepreneurs to identify a reasonable amount of crowd equity. Moreover, because the shares of firms can be hold by strangers, risks and concerns will be raised for entrepreneurs even it is a single non-voting share (Schwartz 2013). Thus, risk management for start-ups used equity crowdfunding method needs to be studied.

\section{Asymmetric information, investment readiness and networks}

Beside the uncertainty of the investment returns, information asymmetry plays an important role in the financial markets (Leland and Pyle 1977). Entrepreneurs and investors unequally access to the information about the new ventures leading to the absence of perfect information (Certo 2003). In fact, entrepreneurs possess more inside information about the true intentions, planned activities, and value of the firms than outside investors (Amit et al. 1990, Prasad et al. 2000); this asymmetric information can lead to the rejection of good investment opportunities or underinvestment (Myers and Majluf 1984). An investment is likely to be undertaken when the financial providers are able to mitigate the risks derived from the information asymmetry problems (Cumming and Johan 2008). However, in equity crowdfunding, the limited disclosure information seems to aggravate the asymmetric information problem between investors and investees (Belleflamme et al. 2014). 
Investors can reduce the information asymmetry regarding to the intentions and planned activities of entrepreneurial teams, and the value of new ventures through contingency (incentive) contracts and monitors (Kreps 1997). The asymmetric information can be alleviated via signals (Certo 2003) conveyed by the knowledgeable parties or/and through screening activity which seeks for additional information from uninformed parties (Lee and Venkataraman 2006, Carpentier et al. 2010). These parties can have direct or indirect relationships with entrepreneurs, and they thus can receive relevant information about the entrepreneurial teams.

Nofsinger and Wang (2011) argued that entrepreneurs at early stages may rely on their social networks. Many scholars have proved that social ties provide a potential mechanism to reduce the information asymmetry between potential investors and entrepreneurs (Uzzi 1996, Freiburg and Grichnik 2012). Social networks also provide additional information about the values of new ventures (Granovetter 2005), and leverage the trust between entrepreneurs and financial providers (Kautonen et al. 2010) eventually positively influence the investment decision. Even Mollick (2014) found that "threshold funding, active participation by large communities, frequent interaction between founders and potential funders, and the ability of founders to broadcast signals of quality” are likely to help the crowd to identify quality projects and reduce the change of fraud, our understanding about the roles of social networks in equity crowdfunding is still limited.

\section{Ownership and control}

Equity crowdfunding not only is the mean for entrepreneurs to share risks to other investors but also disperses their control and governance on start-ups. Shareholders can gain their control of the firms by purchase shares from other holders (Schwartz 2013). The increasing dispersion of 
control may impede the entrepreneurial activities of entrepreneurs in performing their experimentations, adjusting the business strategy, and entrepreneurial innovation. How to balance the benefit of equity crowdfunding with the disadvantages generated by the dispersion of control is a challenged question.

Moreover, in equity crowdfunding, shareholders of start-ups generally have the right to vote and coordinate, and all activities are facilitated through the internet (Schwartz 2013). Agency theory could be adopted to investigate the cost-control mechanisms of equity crowdfunding model which reflect the likely acceptance of the investor-investee relationships in start-up finance. Future research on how the ownership and control rights of crowdfunders can be managed through internet must also be undertaken.

Mollick (2014) found that large numbers of successful crowdfunding projects delated to deliver their promised products because of the increase of crowdfunder's expectations in the complexity and scope of the project. Thus, several relevant questions on how to ensure that initial resource endowments prove adequately to mitigate the risk of delay or failure, how a successful equity crowdfunding project develops and delivers promised products or services, and how entrepreneurs can develop an altering plan if necessitated need to be answered.

\section{Regulatory environment}

The regulation landscape for equity crowdfunding around the world provides a fascinating new financial market (Cumming and Johan 2013). Although over billion dollars invested by millions of crowdfunding backers, complete regulations to encourage the equity crowdfunding activity of entrepreneurs and academic knowledge on this domain are still limited (Mollick 2014). Shiller (2013) believes that equity crowdfunding is not only an exciting concept but also a dangerous 
innovation because it can be used to abuse people, so it needs to be constantly updated and improved. Similar to public offering of a company's securities, equity crowdfunding faces multifaceted challenges including regulatory hurdles, governance and control (Lehner 2013), and requires a high regulation to prevent fraud and ameliorate crowdfunding market. Moreover, Cumming and Johan (2013) proposed that there are potential risks associated with equity crowfunding, such as entrepreneurs dilute the equity stake held by crowdfunders by issuing more shares to themselves, pay themselves more, and not invest in the project after successfully finishing the crowdfunding campaign. Thus, studying the advantages and disadvantages of the current regulations will help policy makers to improve relevant acts to encourage practical equity crowdfunding activities. Future researchers need to find out how to perfect relevant regulations in the national context, as well as in the international environment because equity crowdfunding is a global financing method.

\section{Conclusion}

This paper provides a theoretical review of the extant literature and develops from that review an agenda for future research. The study identifies the core themes of research in relation to equity crowdfunding; these were identified as equity crowdfunding in entrepreneurship context, fund receivers (entrepreneurs), crowdfunders, and regulatory environment (the government). The paper describes how crowdfunding was conceptualised in management studies and how the notion of equity crowdfunding as an alternative source of funding for early stage firms was emerged. The paper also scrutinize the equity crowdfunding within the context of early stage firms from the perspectives of the investor, entrepreneur and government to highlight the contributions made by equity crowdfunding and possible gaps in the literature that could help inform the future research. Based upon the findings of the theoretical review, the paper suggests 
research directions in which future researchers can employ behaviour theory (Connelly et al. 2010), agency theory (Arthurs and Busenitz 2003), and signalling theory (Connelly et al. 2011)

to explore, investigate, and accomplish our understanding about equity crowdfunding in the entrepreneurial context.

\section{References}

Amit, R., Glosten, L. and Muller, E. (1990). Entrepreneurial Ability, Venture Investments, and Risk Sharing. Management Science, 36, 1232-1245.

Arthurs, J.D. and Busenitz, L.W. (2003). The Boundaries and Limitations of Agency Theory and Stewardship Theory in the Venture Capitalist/Entrepreneur Relationship*. Entrepreneurship Theory and Practice, 28, 145-162.

Bayus, B.L. (2013). Crowdsourcing New Product Ideas over Time: An Analysis of the Dell IdeaStorm Community. Management Science, 59, 226-244.

Belleflamme, P., Lambert, T. and Schwienbacher, A. (2013). Individual crowdfunding practices. Venture Capital, 15, 313-333.

Belleflamme, P., Lambert, T. and Schwienbacher, A. (2014). Crowdfunding: Tapping the right crowd. Journal of Business Venturing, 29, 585-609.

Brabham, D.C. (2009). Crowdsourcing the Public Participation Process for Planning Projects. Planning Theory, 8, 242-262.

Bradford, C.S. (2012). The New Federal Crowdfunding Exemption: Promise Unfulfilled. Securities Regulation Law Journal, 40, 195-249.

Cameron, P., Corne, D.W., Mason, C.E. and Rosenfeld, J. (2013). Crowdfunding genomics and bioinformatics. Genome Biology, 14.

Carpenter, R.E. and Petersen, B.C. (2002). CAPITAL MARKET IMPERFECTIONS, HIGH-TECH INVESTMENT, AND NEW EQUITY FINANCING. The Economic Journal, 112, F54-F72.

Carpentier, C., L'her, J.-F. and Suret, J.-M. (2010). Stock exchange markets for new ventures. Journal of Business Venturing, 25, 403-422.

Certo, S.T. (2003). Influencing initial public offering investors with prestige: Signaling with board structures. Academy of Management Review, 28, 432-446.

Chen, X.P., Yao, X. and Kotha, S. (2009). Entrepreneur Passion and Preparedness in Business Plan Presentations: A Persuasion Analysis of Venture Capitalists' Funding Decisions. Academy of Management Journal, 52, 199-214.

Clark, C. (2008). The impact of entrepreneurs' oral 'pitch' presentation skills on business angels' initial screening investment decisions. Venture Capital, 10, 257-279.

Connelly, B.L., Certo, S.T., Ireland, R.D. and Reutzel, C.R. (2011). Signaling Theory: A Review and Assessment. Journal of Management, 37, 39-67.

Connelly, B.L., Ireland, R.D., Reutzel, C.R. and Coombs, J.E. (2010). The Power and Effects of Entrepreneurship Research. Entrepreneurship: Theory \& Practice, 34, 131-149.

Cumming, D. and Johan, S. (2008). Information asymmetries, agency costs and venture capital exit outcomes. Venture Capital, 10, 197-231.

Cumming, D. and Johan, S. (2013). Demand-driven securities regulation: evidence from crowdfunding. Venture Capital, 15, 361-379. 
Cumming, D. and Macintosh, J.G. (2006). Crowding out private equity: Canadian evidence. Journal of Business Venturing, 21, 569-609.

Douglas, E.J. and Shepherd, D. (2002). Exploring investor readiness: assessments by entrepreneurs and investors in Australia. Venture Capital, 4, 219-236.

Dushnitsky, G. and Shapira, Z. (2010). Entrepreneurial Finance Meets Organizational Reality: Comparing Investment Practices and Performance of Corporate and Independent Venture Capitalists. Strategic Management Journal, 31, 990-1017.

Freiburg, M. and Grichnik, D. (2012). Institutional investments in private equity funds: social ties and the reduction of information asymmetry. Venture Capital, 14, 1-26.

Granovetter, M. (2005). The impact of social structure on economic outcomes. Journal of Economic Perspectives, 19, 33-50.

Greenhalgh, T. and Peacock, R. (2005). Effectiveness and efficiency of search methods in systematic reviews of complex evidence: audit of primary sources. British Medical Journal, 331, 1064-1065.

Gruber, M. and Henkel, J. (2006). New ventures based on open innovation - an empirical analysis of start-up firms in embedded Linux. International Journal of Technology Management, 33, 356372.

Hellmann, T. (2007). Entrepreneurs and the process of obtaining resources. Journal of Economics \& Management Strategy, 16, 81-109.

Hempel, J. (2006). Crowdsourcing. BusinessWeek, 38-39.

Howe, J. (2006). The rise of crowdsourcing. Wired Magazine.

Ibrahim, N. and Verliyantina (2012). The Model of Crowdfunding to Support Small and Micro Businesses in Indonesia Through a Web-based platform. International Conference on Small and Medium Enterprises Development with a Theme 'Innovation and Sustainability in Sme Development ' (Icsmed 2012), 4, 390-397.

Kautonen, T., Zolin, R., Kuckertz, A. and Viljamaa, A. (2010). Ties that blind? How strong ties affect small business owner-managers' perceived trustworthiness of their advisors. Entrepreneurship \& Regional Development, 22, 189-209.

Kirsch, D., Goldfarb, B. and Gera, A. (2009). Form or Substance: The Role of Business Plans in Venture Capital Decision Making. Strategic Management Journal, 30, 487-515.

Kreiser, P.M., Marino, L.D., Dickson, P. and Weaver, M.K. (2010). Cultural Influences on Entrepreneurial Orientation: The Impact of National Culture on Risk Taking and Proactiveness in SMEs. Entrepreneurship: Theory \& Practice, 34, 959-983.

Kreps, D.M. (1997). Intrinsic motivation and extrinsic incentives. American Economic Review, 87, 359364.

Larralde, B. and Schewienbacher, A. (2012). Crowdfunding of small entrepreneurial ventures. In Cumming, D. (ed.), The Oxford Handbook of Entrepreneurial Finance. New York: Oxford University Press.

Lee, J.H. and Venkataraman, S. (2006). Aspirations, market offerings, and the pursuit of entrepreneurial opportunities. Journal of Business Venturing, 21, 107-123.

Lehner, O.M. (2013). Crowdfunding social ventures: a model and research agenda. Venture Capital, 15, 289-311.

Leland, H.E. and Pyle, D.H. (1977). Informational Asymmetries, Financial Structure, and Financial Intermediation. Journal of Finance, 32, 371-387.

Ley, A. and Weaven, S. (2011). EXPLORING AGENCY DYNAMICS OF CROWDFUNDING IN START-UP CAPITAL FINANCING. Academy of Entrepreneurship Journal, 17, 85-110.

Lindstrom, G. and Olofsson, C. (2001). Early stage financing of NTBFs: an analysis of contributions from support actors. Venture Capital, 3, 151-168. 
Loucks, D. (2013). Will crowdfunding and general solicitation spur orphan drug development for biotechs? Formulary, 48, 343-344.

Macpherson, A. and Jones, O. (2010). Editorial: Strategies for the Development of International Journal of Management Reviews. International Journal of Management Reviews, 12, 107-113.

Mason, C.M. and Harrison, R.T. (2004). Does investing in technology-based firms involve higher risk? An exploratory study of the performance of technology and non-technology investments by business angels. Venture Capital, 6, 313-332.

Maxwell, A.L., Jeffrey, S.A. and Lévesque, M. (2011). Business angel early stage decision making. Journal of Business Venturing, 26, 212-225.

Meseri, O. and Maital, S. (2001). A Survey Analysis of University-Technology Transfer in Israel: Evaluation of Projects and Determinants of Success. The Journal of Technology Transfer, 26, 115-125.

Mollick, E. (2014). The dynamics of crowdfunding: An exploratory study. Journal of Business Venturing, 29, 1-16.

Myers, S.C. and Majluf, N.S. (1984). Corporate Financing and Investment Decisions When Firms Have Information That Investors Do Not Have. Journal of Financial Economics, 13, 187-221.

Nofsinger, J.R. and Wang, W. (2011). Determinants of start-up firm external financing worldwide. Journal of Banking \& Finance, 35, 2282-2294.

Ordanini, A., Miceli, L., Pizzetti, M. and Parasuraman, A. (2011). Crowd-funding: transforming customers into investors through innovative service platforms. Journal of Service Management, 22, 443470.

Poetz, M.K. and Schreier, M. (2012). The Value of Crowdsourcing: Can Users Really Compete with Professionals in Generating New Product Ideas? Journal of Product Innovation Management, 29, 245-256.

Prasad, D., Bruton, G.D. and Vozikis, G. (2000). Signaling value to businessangels: the proportion of the entrepreneur's net worth invested in a new venture as a decision signal. Venture Capital, 2, 167182.

Riedl, J. (2013). Crowdfunding Technology Innovation. Computer, 46, 100-103.

Schwartz, A.A. (2013). CROWDFUNDING SECURITIES. Notre Dame Law Review, 88, 1457-1490.

Shane, S. and Cable, D. (2002). Network ties, reputation, and the financing of new ventures. Management Science, 48, 364-381.

Shiller, R.J. (2013). Capitalism and Financial Innovation. Financial Analysts Journal, 69, 21-25.

Sigar, K. (2012). FRET NO MORE: INAPPLICABILITY OF CROWDFUNDING CONCERNS IN THE INTERNET AGE AND THE JOBS ACT'S SAFEGUARDS. Administrative Law Review, 64, 473-506.

Sorensen, I.E. (2012). Crowdsourcing and outsourcing: the impact of online funding and distribution on the documentary film industry in the UK. Media Culture \& Society, 34, 726-743.

Stemler, A.R. (2013). The JOBS Act and crowdfunding: Harnessing the power-and money-of the masses. Business Horizons, 56, 271-275.

Tranfield, D., Denyer, D. and Smart, P. (2003). Towards a methodology for developing evidenceinformed management knowledge by means of systematic review. British Journal of Management, 14, 207-222.

Uzzi, B. (1996). The sources and consequences of embeddedness for the economic performance of organizations: The network effect. American Sociological Review, 61, 674-698.

Weigmann, K. (2013). Tapping the crowds for research funding - Crowdfunding, a common practice to support projects in the arts, music or gaming, has also attracted the attention of scientists. Embo Reports, 14, 1043-1046.

Widding, L.O., Mathisen, M.T. and Madsen, O. (2009). University-affiliated Venture Capital funds: funding of University Spin-Off companies. International Journal of Technology Transfer \& Commercialisation, 8, 229-245. 
Wieck, E., Bretschneider, U. and Leimeister, J.M. (2013). FUNDING FROM THE CROWD: AN INTERNETBASED CROWDFUNDING PLATFORM TO SUPPORT BUSINESS SET-UPS FROM UNIVERSITIES. International Journal of Cooperative Information Systems, 22.

Wiltbank, R., Read, S., Dew, N. and Sarasvathy, S.D. (2009). Prediction and control under uncertainty: Outcomes in angel investing. Journal of Business Venturing, 24, 116-133.

Zahra, S.A., Gedajlovic, E., Neubaum, D.O. and Shulman, J.M. (2009). A typology of social entrepreneurs: Motives, search processes and ethical challenges. Journal of Business Venturing, 24, 519-532.

Zahra, S.A., Rawhouser, H.N., Bhawe, N., Neubaum, D.O. and Hayton, J.C. (2008). Globalization of Social Entrepreneurship Opportunities. Strategic Entrepreneurship Journal, 2, 117-131.

Zhang, J. and Wong, P.-K. (2008). Networks vs. market methods in high-tech venture fundraising: the impact of institutional environment. Entrepreneurship \& Regional Development, 20, 409-430. 